in Marin County, north of San Francisco, where conditions are so extreme that the water district has imposed a mandatory water use limit of 50 gallons per person per day. The county ran a pilot desalination plant for three months last autumn, using the process of reverse osmosis to remove salt by forcing seawater through fine membranes.

Voters will decide in November whether to build a $\$ 60-\$ 120$ million permanent plant, rather than building pipelines to import river water from a neighbouring region.

A desalination project about ten times larger, designed to generate 100 million gallons of drinking water a day, is under consideration by a team of Southern California utility companies.

A six-month, $\$ 600,000$ study started this month to evaluate the feasibility of constructing the plant across the California border in Mexico. Rather than reverse osmosis, the huge project may use the other common desalination technology, distillation, in which the sea water is boiled and the fresh water condensation collected.

There are those in California who are not content with harnessing the sea and the clouds for fresh water, but who are thinking even bigger - on the scale of rearranging the entire North American continent to equalize the fresh-water supplies which are concentrated in Alaska and Canada. Ideas for ambitious projects have been tossed around for decades, but one of the most overwhelming was revived last year by a group now known as Citizens for Water and Power in North America, Inc. (WAPNA).

Led by Robert Finch, a former lieutenant governor of California, WAPNA proposes to dam three rivers in Alaska and Canada's Yukon Territory, and direct water through a vast chain of reservoirs, dams and trenches into the largest water catchment ever attempted - a 500-mile-long reservoir created from a gorge in the Canadian Rockies before delivering water to 23 states in the United States as well as regions of Canada and Mexico.

The project would take 30 years to build, planners estimate, so clearly would not ease this drought, but it might relieve the next one. Planners say the project, at an estimated cost of $\$ 300,000$ million, would deliver 160 million acre-feet of water per year. (California consumes about 34 million acre-feet per year.) It would also yield 70,000 MW of hydroelectric power, of which $30,000 \mathrm{MW}$, or about 10 per cent of the current American consumption, would go to the United States.

Various proposals for massive relocations of water have been put forward for years, but nothing close to this magnitude has been successful. Mega-projects are inherently difficult to nurture, given the daunting political and financial hurdles they must surmount, not to mention opposition from environmental groups.

Finch, however, hopes that the current drought may provide him with more sympathetic listeners.

\title{
Budget cuts for research
}

\section{Paris}

FRENCH researchers will have to tighten their belts over the next few years as a result of a significant slowing in the nation's economic growth, made worse by the cost of the Gulf War.

Initially forecast at 2.7 per cent, growth this year is running at 1.5 per cent, mostly because of reductions in rates of value-added tax to bring France in line with its European neighbours.

Last week, the finance minister announced cuts of around FF1,000 million (\$189 million) in the FF48,700 million 1991 civil research budget. But cancelled programmes whose cost was to be spread over several years mean a further FF2,400 million will be lost. Instead of progressing by 6 per cent, as promised, the civil research budget will now be only 0.5 per cent ahead of inflation, currently estimated at 2.5 per cent.

At the ministry for research and technology (MRT) there is a mixture of relief and concern. Denis Plantant, budgetary adviser to research minister Hubert Curien, says that the cuts are "less than we expected initially".

This year, MRT's budget has been cut by FF200 million ( 0.8 per cent), although when cancelled long-term investments are taken into account, the figure is FF349 million. But, adds Plantant, the effects on the re- search organizations (such as the Centre National de la Recherche Scientifique, CNRS) will be "not negligible".

These organizations, responsible for most of the nation's basic research, will be especially affected by cancelled long-term programmes, while their budgets for laboratory running costs are also to be reduced by 3 per cent. CNRS alone will lose FF64 million this year (out of a FF11,100 million annual budget), with more than FF102,000 million cut from long-term investments in equipment and construction.

Although the research organizations are to bear the brunt of the new cuts, the government's priority areas - industrial research and the universities - have been largely protected. University research and teaching have not been touched, while spending on industrial research is down FF40 million out of a total budget of FF4,000 million.

France is a major contributor to European technology programmes and to the European Space Agency, but the cuts announced in these sectors are minimal. "France will be able to honour her commitments", says Plantant.

But one official close to the research minister says that French spending on space projects - including the Hermes space shuttle and Ariane 5 launcher - will come under the microscope again in "late spring or early summer".

Peter Coles BRITISH TECHNOLOGY GROUP

\section{Universities considering a buy-out}

\section{London}

BRITISH universities, anxious to protect their $£ 13$ million annual income from the government-owned British Technology Group (BTG), may try to buy a stake in the company when it is sold into the private sector.

BTG is Britain's largest technology transfer organization. In return for a share in any commercial profits, BTG helps inventors with patent applications, negotiates licence agreements with manufacturing companies, and may even provide funding for research and development (R\&D). A government bill to privatize BTG is now passing through parliament (see Nature 349, 272; 24 January 1991).

Although welcomed by senior BTG management, the move was attacked by the opposition Labour party, which argues that private ownership would restrict BTG to backing inventions that are likely to give commercial returns in the short term.

The universities receive about $£ 7.5$ million a year from BTG in R\&D grants, plus some $£ 5.5$ million in royalties from BTGpatented inventions. The Committee of Vice-Chancellors and Principals (CVCP) considered the likely impact of the privatiz- ation at a meeting earlier this month, where several vice-chancellors argued that a buy-out is the best option to protect the universities' long-term financial interest in BTG.

But BTG's price tag, at $£ 35$ million, is more than the financially stretched universities can afford. CVCP staff are now investigating the possibility of putting together a consortium to share the cost of a BTG buyout, making discreet advances to other interested bodies, including large British research foundations.

A university-led buy-out would ease the concerns of university-based inventors, but some resentment over the government's handling of the privatization would remain. Peter Mansfield, from the University of Nottingham, who in the early 1970s developed Magnetic Resonance Imaging, one of the outstanding commercial successes in the BTG portfolio, says that the government and BTG have ignored the views of BTG's inventors, whilst consulting with "all sorts of secondary bodies", such as the CVCP. Mansfield would like to see shares in BTG offered to the investors responsible for "the creative work" behind BTG's commercial success. 